\title{
The history of Holocene atmospheric iodine over the North Atlantic
}

Carlos Alberto Cuevas ${ }^{1}$, Juan Pablo Corella1, Niccolo Maffezzoli2,3, Paul Vallelonga², Andrea Spolaor ${ }^{3}$, Giulio Cozzij, Juliane Müller 4,5 , Bo Vinther ${ }^{2}$, Carlo Barbante ${ }^{3,6}$, Helle Astrid Kjaer ${ }^{2}$, Ross Edwards ${ }^{7,8}$, and Alfonso Saiz-Lopez ${ }^{1}$

1 Department of Atmospheric Chemistry and Climate, Institute of Physical Chemistry Rocasolano, CSIC,Serrano 119, 28006 Madrid, Spain

2 Physics of Ice Climate and Earth, Niels Bohr Institute, University of Copenhagen, Tagensvej 16, Copenhagen N 2200,Denmark 3 Institute of Polar Sciences, ISP-CNR, Via Torino 155, 30170 Venice, Italy

4 Alfred Wegener Institute, Helmholtz Center for Polar and Marine Research, Am Alten Hafen 26,27568 Bremerhaven, Germany 5 MARUM Research Faculty, University of Bremen, Leobener Strasse 8, 28359 Bremen, Germany

6 Department of Environmental Sciences, Informatics and Statistics, Ca'Foscari University of Venice, Via Torino 155,30170 Venice, Italy

7 Physics and Astronomy, Curtin University, Kent St, Bentley WA 6102, Australia

8 Department of Civil and Environmental Engineering, UW-Madison, Madison, WI 53706, USA

Corella et al., 2019: Holocene atmospheric iodine evolution over the North Atlantic. Clim. Past, 15, 2019-2030, 2019. https://doi.org/10.5194/cp-15-2019-2019

Cuevas et al., 2018: Rapid increase in atmospheric iodine levels in the North Atlantic since the mid 20 th century. Nat. Commun., 9, 1452. https://doi.org/10.1038/s41467-018-03756-1 


\section{Introduction}

Atmospheric iodine chemistry has a large influence on the oxidizing capacity and associated radiative impacts on the troposphere.

Direct instrumental measurements of atmospheric iodine are restricted to the last decades, preventing us from understanding the long term biogeochemical cycle of iodine and further environmental and climatic implications. Ice core records partially overcome these limitations since these natural archives sensitively record continuous atmospheric iodine levels in polar regions.

In this study we report (from the Greenland-ReCAP ice core record) the first and continuous reconstruction of iodine levels (i.e. iodine concentration [I] and iodine depositional fluxes $\left(I_{\text {flux }}\right)$ ) in the Northern Hemisphere since the onset of the Holocene (last 11700 years). This exceptional natural archive, provide us with an analytical framework to investigate, for the first time, the evolution of atmospheric iodine in the Arctic since the Holocene.

The global 3D chemistry-climate model CAM-Chem, is used to study how the ozone-driven emissions of iodine $\left(\mathrm{HOI}\right.$ and $\left.\mathrm{I}_{2}\right)$ may have controlled the variability of atmospheric iodine during the 1950-2010 time period.

This study also provides a unique insight into the environmental drivers controlling the long term atmospheric iodine biogeochemical cycle in the Arctic 


\section{The ReCAP (Renland Ice Cap) ice-core}

Drilled at $71,30^{\circ} \mathrm{N}, 26,72^{\circ} \mathrm{W}, 2315 \mathrm{~m}$ asl.

$584 \mathrm{~m}$ ice drilled to bedrock by the Centre for Ice and Climate of the University of Copenhagen in 2015

Here we report lodine and Sodium in a depth-range spanning the Holocene period (last $11.7 \mathrm{kyr} \mathrm{BP}$ ) from the upper $535 \mathrm{~m}$ of the ice-core.

Measurements of ${ }^{127} \mid$ and ${ }^{23} \mathrm{Na}$ carried out at the Environmental Analytical Chemistry Laboratory of the IDPA-CNR, University Ca'Foscari in Venice (Italy), using an Inductively Collision Reaction Cell Inductively Coupled Plasma Mass Spectrometry (CRC-ICP-MS) and an Inductively Coupled Plasma Sector Field Mass Spectroscopy (ICP-SFMS) lodine (127I) was determined at low mass resolution with stability of instrumental signal evaluated by the continuous monitoring of ${ }^{129} \mathrm{Xe}$
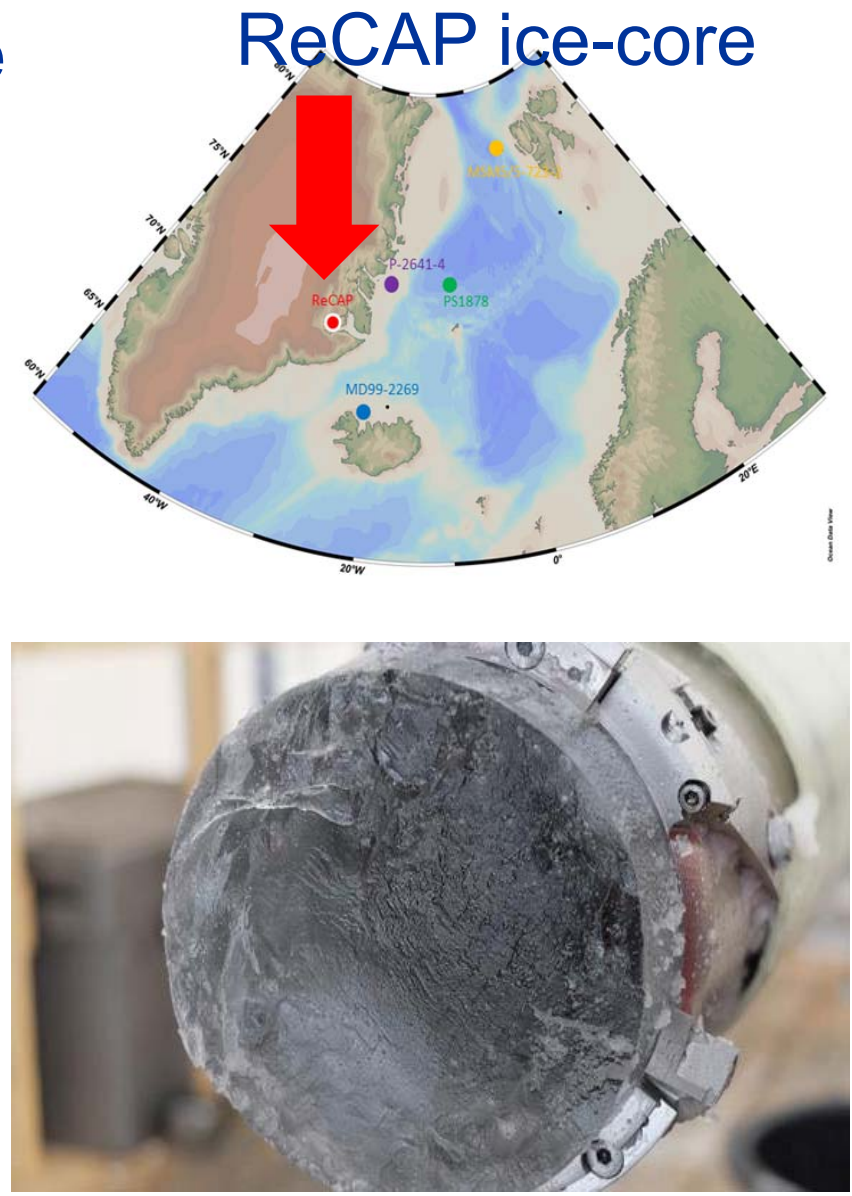


\section{The CAM-Chem model}

3D chemistry-climate model within the CESM framework (Community Earth System Model) (Lamarque et al., 2012)

Model setup based on CCMI-REFC1 experiment

Updated chemistry scheme for halogens (chlorine, bromine and iodine) (Ordóñez et al., 2012, Fernandez et al. 2017, Saiz-lopez et al., 2014, 2015)

Includes an explicit state-of-the-art scheme of iodine emissions (both organic and inorganic) and photochemistry (both gas and particle phase), which account for chemical transformation during transport from the ocean source to deposition in the Renland region

$1.9^{\circ}$ latitude $\times 2.5^{\circ}$ longitude spatial resolution and 26 vertical levels $(0-40 \mathrm{~km})$

The model was run in free-running mode considering prescribed sea surface temperatures and sea ice distributions from 1950 to 2010 (MERRA reanalysis dataset) 


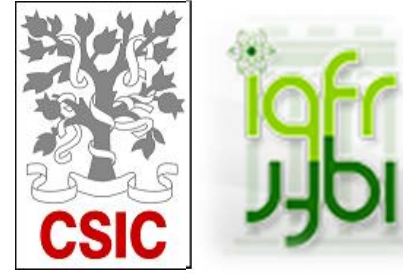

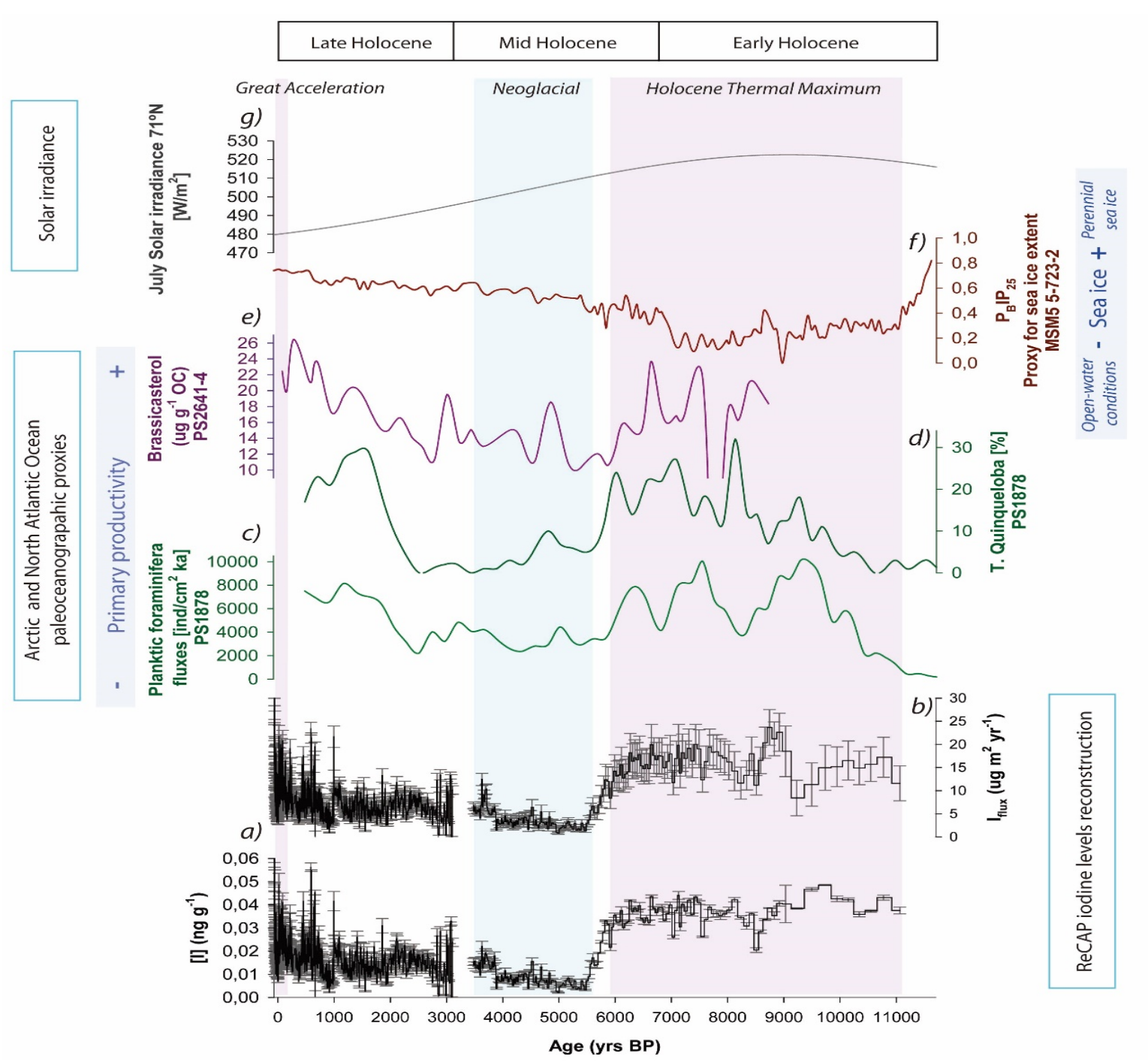

Holocene iodine

concentrations and fluxes evolution from the ReCAP ice core and primary productivity and sea-ice cover proxies from the Nordic seas (Figure 2)

From bottom to top:

a) lodine concentrations ( $1 \sigma$, experimental uncertainties; (lodine detection limits are within 0.005 and $0.002 \mathrm{ppb}$ )

b) lodine fluxes ( $1 \sigma$, propagated from the concentration and accumulation rate uncertainties) ( $\mathrm{N}=1050)$;

c) and d) Planktic foraminifera and $T$. quinqueloba (core PS1878) (M Telesiński et al., 2015)

e) Brassicasterol (core PS2641-4) (Müller et al., 2012)

f) Sea-ice cover (core MSM5 5/723-2) (Werner et al., 2013; Werner et al., 2016)

g) $71^{\circ} \mathrm{N}$ July solar irradiance

Color boxes indicate the Holocene main climatic periods mentioned in the text; pink boxes indicate warmer phases while blue boxes indicate colder intervals. 


\section{Atmospheric iodine evolution during the Holocene}

a Holocene Thermal Maximum

(10-5.5 kyr BP)

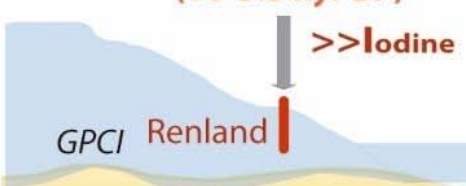

\section{Biological lodine Explosion (BIE)}

High biogenic iodine emissions
Higher solar irradiance

(increase in algae

metabolic stress)
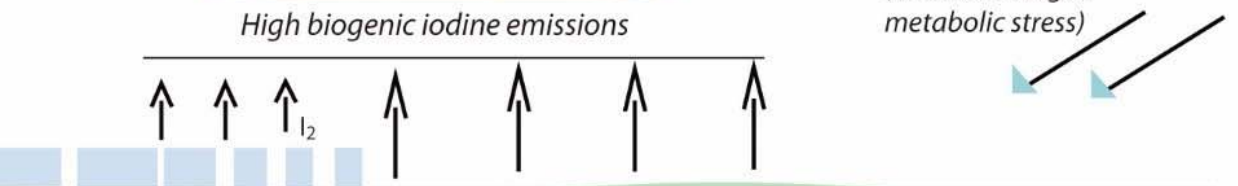

Sea-ice algae

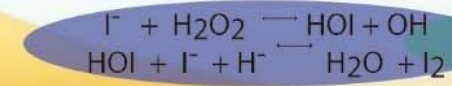

$\mathrm{CH}_{3} \mathrm{I}, \mathrm{CH}_{2} \mathrm{I}_{2}, \mathrm{CH}_{2} \mathrm{ICl}, \mathrm{CH}_{2} \mathrm{IBr}$ and $\mathrm{C}_{2} \mathrm{H}_{5} \mathrm{I}$

$\uparrow \uparrow S S T$

Halocline

SST Sea surface temperature

GPCI Greenland perennial continental ice

\begin{tabular}{c|l|ll|}
$\begin{array}{c}\text { Paleoenvironmental } \\
\text { scenario }\end{array}$ & $\begin{array}{l}\text { Nearly absent multi-year sea ice } \\
\text { Seasonal first-year sea ice being } \\
\text { replaced by open ocean }\end{array}$ & $\begin{array}{l}\text { Dominant open-water conditions } \\
\text { Large blooms of phytoplankton } \\
\text { and algal communities }\end{array}$ & $\begin{array}{c}\text { Maxima in solar irradiance } \\
\text { from living organisms }\end{array}$ \\
\hline
\end{tabular}

Maximum organic iodine emissions were recorded during this period (fig $2 \mathrm{a}$ in previous slide). The rise of atmospheric iodine levels at the onset of this warm period was due to a Biological lodine Explosions (BIEs). BIE resulted from the interplay of different factors:

- Enhanced ocean primary productivity and dominant open water conditions in the Arctic ocean, leading to massive emissions of iodine from the oceans to the atmosphere

- Maxima in solar irradiance in the Arctic increased the algae oxidative stress, leading to an enhancement of the biological iodine production in the ocean and subsequent release to the atmosphere

- Higher sea surface temperatures (SST), favoring the sea air phase transfer of iodine compounds produced in the ocean surface 


\section{Neoglacial Period (5.5 3.4 krys BP)}

b Neoglacial Period (5.5-3.4 kyr BP)

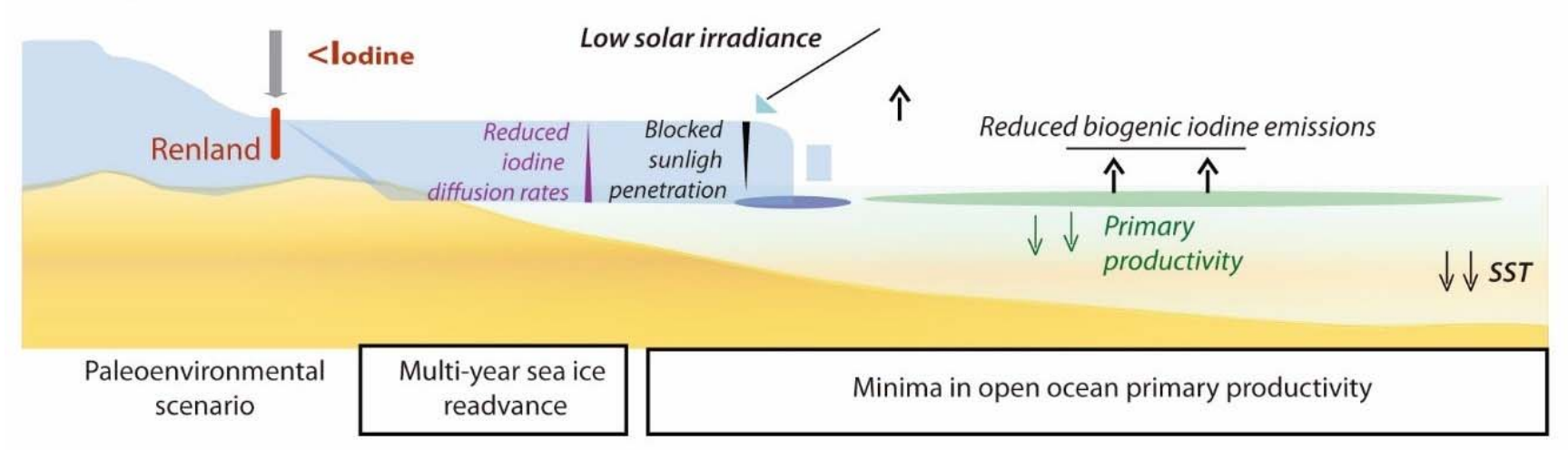

lodine values were significantly reduced during this period Three factors controlled the atmospheric iodine levels drop

- Sunlight could not penetrate through the densely packed ice impeding sea ice diatoms blooms.

- Thicker sea ice reduced the iodine diffusion rates

- The reduction in solar insolation diminished algae metabolic activity and hence iodine production in the open ocean 


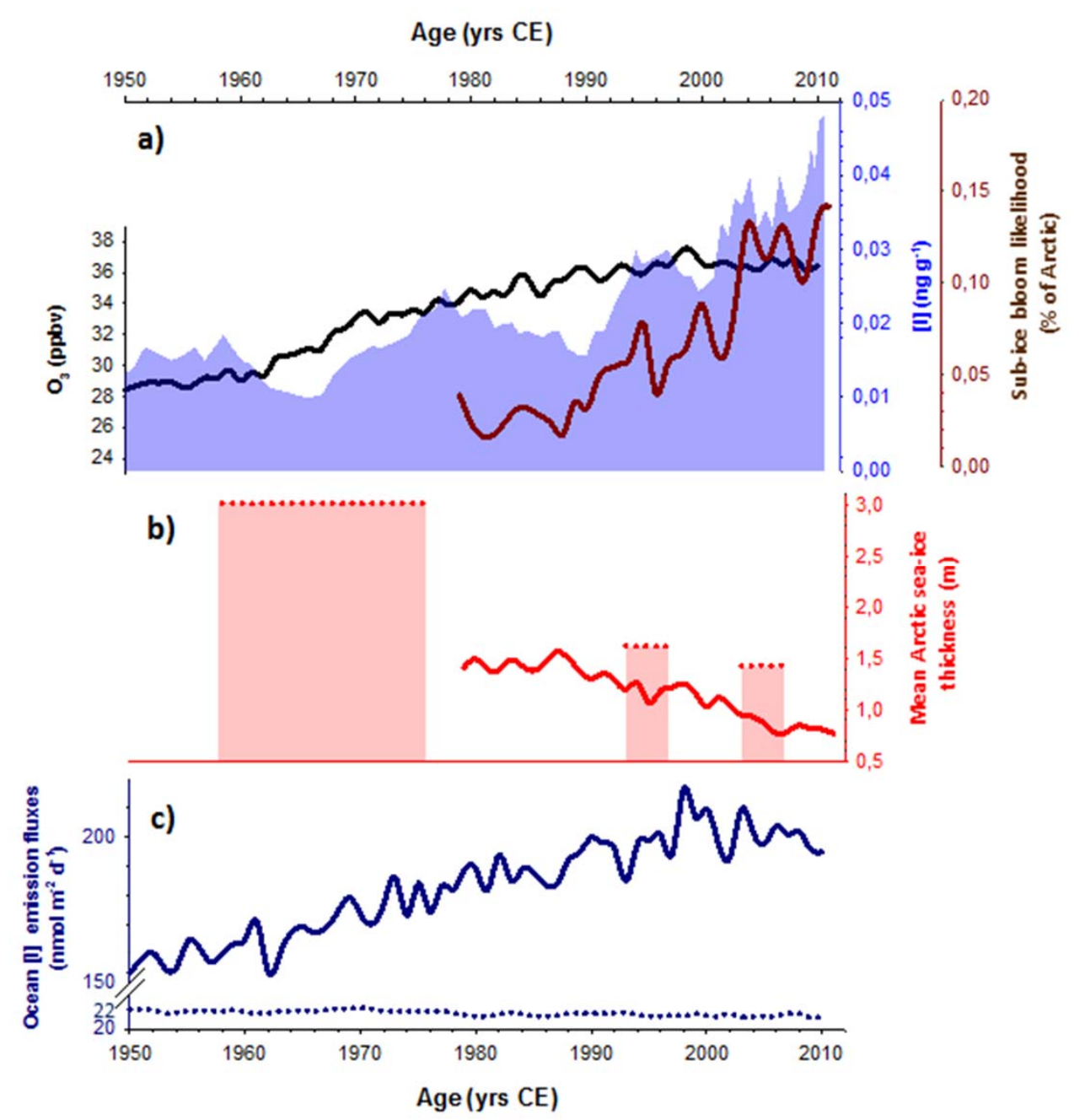

\section{lodine concentration evolution and forcing mechanisms for the period 1950 - 2011 (figure 5)}

From top to bottom:

a) iodine concentration (blue area); ozone annually averaged over the North Atlantic region (latitude: $20 \mathrm{~N}-70 \mathrm{~N}$,

longitude $=75 \mathrm{~W}-0$ ) (dark line) and evolution of the pan-Arctic likelihood of sub-ice blooms in late spring and early summer (May-June-July) over time (Horvat et al., 2017) (read line)

b) mean Arctic sea ice thickness, red line from Horvat et al. 2017 and red dots from Kwok et al. 2009

c) CAM-Chem modelled ocean emission fluxes of iodine with (solid line) and without (dotted line) the implementation of the ozone-induced iodine emission mechanism. 


\section{Great Acceleration (1950s Present dayAtmospheric iodine evolution during the Holocene}

C Great Acceleration (1950s- Present day)

Anthropogenic ozone-induced iodine emissions

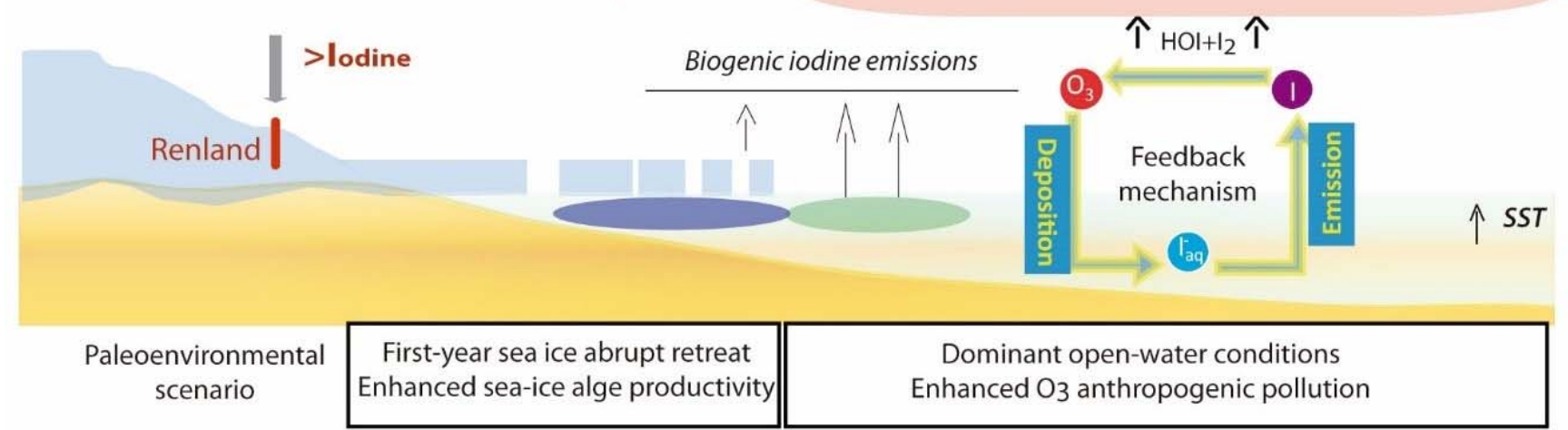

lodine levels doubled since the beginning of the Industrial Period and tripled since 1950 (Figs 5 in previous slide). This increase is driven by anthropogenic ozone pollution and enhanced sub ice phytoplankton production associated with the recent thinning of Arctic sea ice. The global 3D chemistryclimate model CAM-Chem, also shows that increasing atmospheric iodine has accelerated ozone loss and considerably increased iodine transport and deposition to the Northern hemisphere continents since 1950 


\section{Atmospheric implications}

- The abrupt long term fluctuations in atmospheric iodine levels most likely had a significant impact on the Northern Hemisphere (paleo) atmosphere by decreasing ozone radiative forcing and promoting aerosol nucleation through ocean biology, iodine chemistry and climate feedback mechanisms

- The transport of marine iodine and its deposition to the North American and European continents have increased by $38 \%$ and $25 \%$ respectively, during the past 50 years The enhancement of iodine deposition over continents and the subsequent adsorption onto soil and vegetation is important since it is estimated that 2 billion people worldwide still have insufficient iodine intake.

- The sustained growth in iodine concentrations in the Arctic during the last decades, most likely due to human influences on tropospheric ozone and recent climate change, will accelerate tropospheric ozone loss affecting the oxidative capacity of the atmosphere and the ozone radiative forcing. Future climate and anthropogenic forcing may continue to amplify oceanic iodine emissions, with potentially significant health and environmental impacts at a global scale.

- lodine levels evolution during past warmer phases with near ice free conditions in the Arctic may be used as an analog to predict iodine trends in future warmer scenarios 


\section{References}

- Corella, J.P, Maffezzoli, N., Cuevas, C.A., Vallelonga, P., Spolaor, A,, Cozzi, G., Müller, J., Vinther, B., Barbante, C. Kjær, H.A., Edwards, R. and SaizLopez, A.: Holocene atmospheric iodine evolution over the North Atlantic. Clim. Past, 15, 2019-2030. https://doi.org/10.5194/cp-15-2019-2019, 2019

- $\quad$ Cuevas, C. A., Maffezzoli, N., Corella, J. P., Spolaor, A., Vallelonga, P., Kjær, H. A., Simonsen, M., Winstrup, M., Vinther, B., and Horvat, C.: Rapid increase in atmospheric iodine levels in the North Atlantic since the mid-20th century, Nat. Commun., 9, 1452, https://doi.org/10.1038/s41467-01803756-1, 2018.

- $\quad$ Fernandez, R. P., Kinnison, D. E., Lamarque, J. F., Tilmes, S., and Saiz-Lopez, A.: Impact of biogenic very short-lived bromine on the Antarctic ozone hole during the 21st century, Atmos. Chem. Phys., 17, 1673-1688, 10.5194/acp-17-1673-2017, 2017.

- $\quad$ Horvat, C., Jones, D. R., lams, S., Schroeder, D., Flocco, D., and Feltham, D.: The frequency and extent of sub-ice phytoplankton blooms in the Arctic Ocean, Science Advances, 3, 10.1126/sciadv.1601191, 2017.

- Kwok, R., and Rothrock, D. A.: Decline in Arctic sea ice thickness from submarine and ICESat records: 1958-2008, Geophys. Res. Lett., 36, n/a-n/a, 10.1029/2009GL039035, 2009.

- $\quad$ Lamarque, J. F., Emmons, L. K., Hess, P. G., Kinnison, D. E., Tilmes, S., Vitt, F., Heald, C. L., Holland, E. A., Lauritzen, P. H., Neu, J., Orlando, J. J., Rasch, P. J., and Tyndall, G. K.: CAM-chem: description and evaluation of interactive atmospheric chemistry in the Community Earth System Model, Geosci. Model Dev., 5, 369-411, 10.5194/gmd-5-369-2012, 2012.

- $\quad$ Müller, J., Werner, K., Stein, R., Fahl, K., Moros, M., and Jansen, E.: Holocene cooling culminates in sea ice oscillations in Fram Strait, Quaternary Sci. Rev., 47, 1-14, 2012.

- $\quad$ Ordóñez, C., Lamarque, J. F., Tilmes, S., Kinnison, D. E., Atlas, E. L., Blake, D. R., Sousa Santos, G., Brasseur, G., and Saiz-Lopez, A.: Bromine and iodine chemistry in a global chemistry-climate model: description and evaluation of very short-lived oceanic sources, Atmos. Chem. Phys., 12, 14231447, 10.5194/acp-12-1423-2012, 2012.

- Saiz-Lopez, A., Fernandez, R. P., Ordóñez, C., Kinnison, D. E., Gómez Martín, J. C., Lamarque, J. F., and Tilmes, S.: lodine chemistry in the troposphere and its effect on ozone, Atmos. Chem. Phys., 14, 13119-13143, 10.5194/acp-14-13119-2014, 2014

- $\quad$ Saiz-Lopez, A., Baidar, S., Cuevas, C. A., Koenig, T. K., Fernan-dez, R. P., Dix, B., Kinnison, D. E., Lamarque, J. F., Rodriguez-Lloveras, X., Campos, T. L., and Volkamer, R.: Injection of io-dine to the stratosphere, Geophys. Res. Lett., 42, 6852-6859,doi:10.1002/2015gl064796, 2015.

- $\quad$ Telesiński, M., Bauch, H. A., Spielhagen, R. F., and Kandiano E. S.: Evolution of the central Nordic Seas over the last 20 thousand years, Quaternary Sci. Rev., 121, 98-109, 2015.

- Werner, K., Spielhagen, R. F., Bauch, D., Hass, H. C., and Kandiano, E.: Atlantic Water advection versus sea-ice advances in the eastern Fram Strait during the last 9 ka: Multiproxy evidence for a two-phase Holocene, Paleoceanography, 28, 283-295, 2013.

- Werner, K., Müller, J., Husum, K., Spielhagen, R. F., Kandiano, E. S., and Polyak, L.: Holocene sea subsurface and surface water masses in the Fram Strait-Comparisons of temperature and sea-ice reconstructions, Quaternary Sci. Rev., 147, 194-209, 2016. 


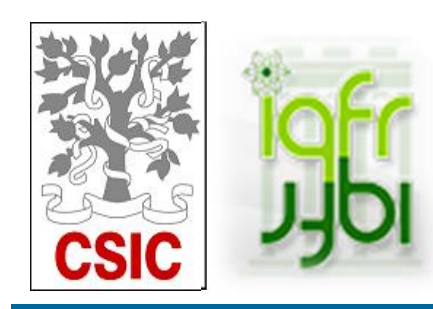

\section{Acknowledgements}

This work was supported by CSIC. The RECAP ice coring effort was financed by the Danish Research Council through a Sapere Aude grant, the NSF through the Division of Polar Programs, the Alfred Wegener Institute, and the European Research Council under the European Community's Seventh Framework Programme (FP7/2007-2013), and an ERC grant agreement 610055 through the Ice2lce project and the Early Human Impact project (267696). This study has received funding from the European Research Council Executive Agency under the European Union's Horizon 2020 Research and Innovation program (Project ERC-2016-COG 726349 CLIMAHAL). 